\title{
Stability and changes during the twentieth century in the breeding landbirds of Tahiti (Polynesia)
}

\author{
CLAUDE MONNET, JEAN-CLAUDE THIBAULT and ALBERT VARNEY
}

\section{Summary}

The distribution of Tahitian landbirds in the early twentieth century and at present is presented here together with maps. Three categories may be recognized: (1) species with a declining distribution owing to changes in habitats (Green-backed Heron), (2) stable or increased species, including local and earlier introduced species, and (3) newly introduced species (Zebra Dove, Red-vented Bulbul, Silvereye and Crimson-backed Tanager). Moreover, owing to their low population numbers, two species, the Pacific Pigeon and the Tahiti Monarch, are on the verge of extinction even if their distribution has not changed notably during this century.

Les répartitions des oiseaux terrestres reproducteurs de Tahiti, au début et à la fin du zoe siècle, sont présentées sous forme de cartes. Trois catégories d'espèces sont distinguées: (1) espèce dont la répartition est en déclin à la suite des modifications d'habitats (Héron vert), (2) espèces stable ou en légère augmentation, chez qui on trouve des oiseaux locaux et des oiseaux introduits, et enfin (3) les espèces introduites durant le 2oe siècle (Tourterelle striée, Bulbul à ventre rouge, Zosterops à poitrine grise et Tangara cramoisi). Il apparaît que deux espèces, le Carpophage du Pacifique et le Monarque de Tahiti, sont aujourd'hui très menacées, même si leur répartition n'a pas régressé d'une façon significative.

\section{Introduction}

Tahiti, a remote island in the central Pacific Ocean, has an avifauna which is a well-known example of species impoverishment mentioned in biogeographical studies (e.g. Mayr 1939). Like other Polynesian islands, it has actually suffered many extinctions (Steadman 1988), first after the Polynesians' arrival 13 centuries ago (Belwood 1978), then after the Europeans' arrival in the eighteenth and nineteenth centuries (Thibault 1988). The main reasons were hunting, introduction of animals, and changes in habitats. Unfortunately, in spite of recent research (Steadman 1988), it will probably be impossible to know the exact number of extinct species.

Between the beginning and the middle of the twentieth century little modification of habitats occurred on Tahiti. But, during the period 1960-1990, many developments have modified the Tahitian landscape: marsh-draining, channelization, coastal urbanization, forest clearance around the lagoon and at estuaries (Blanchet 1986). In the 1980s hydroelectric power schemes caused modi- 
fication of inland habitats through the opening up of tracks and forest clearance. Another important ecological change was the recent invasion by a plant (Miconia calvescens), which was introduced in 1937 and has drastically modified the vegetation of the island in the last 10 years, thus contributing to the progressive disappearance of local trees (Birnbaum 1992).

Tahiti currently holds three globally threatened forms, the Pacific Pigeon, the Tahiti Swiftlet and the Tahiti Monarch (see Collar and Andrew 1988), and another threatened at a regional scale, the Green-backed Heron (Thibault 1988).

The aims of this paper are: (1) to compare the current situation of breeding landbirds with that obtaining early in the century, and (2) to show their present distribution.

\section{Study area and methods}

Tahiti ( $17^{\circ} 38^{\prime} \mathrm{S} 149^{\circ} 30^{\prime} \mathrm{W}$ ), French Polynesia, is a tropical volcanic island. It measures $1,042 \mathrm{~km}^{2}$ and reaches a height of $2,241 \mathrm{~m}$.

Between September 1920 and April 1923, the Whitney South Sea Expedition (hereafter WSSE) stayed approximately nine months on Tahiti spread over several visits, collecting birds for the American Museum of Natural History, New York (Bryan ms). Ernest Quayle was primarily engaged in collecting, but he evidently noted all of the land and freshwater bird species he encountered, except that he probably did not consistently record all introduced species. He explored the island more intensively than the other members of the expedition, and in his journal he noted ecological observations as few naturalists did at this time. He spent several full days in each valley and usually passed the night camping there. He mentioned 19 localities where he collected (or observed) birds. We have identified 15 of them, four being impossible to locate, partly because names are different today, but also because the information quoted in his journal was insufficiently detailed. From 1986 to 1991, 14 of these localities were investigated, the remaining one (Vaiote), although visited by one of us in 1973, not being taken account of.

We are thus in a position to compare the distribution of breeding landbirds in these 14 localities as it stood in 1920-1923 with the situation in 1986-1991. Figure 1a shows localities visited by the WSSE; 25 other localities were also visited in 1986-1991, so a total of 39 were checked during this latter period (Figure 1b). Total time of observation spent in the 14 localities was similar between the two periods (1920-1923: 39 days, $1-9$ days per valley, $x=3$ \pm 2.35; 1986-1991: 41 days, $1-8$ days per valley, $x=2.8 \pm 2.15$ ). Methodology of observation differed in that Ernest Quayle did not use binoculars.

Our geographical unit for the mapping of Tahiti corresponds to valleys defined by their hillsides. On both the mainland and the peninsula the shape of the ancient volcanoes has given a relatively regular distribution to the valleys and their dividing ridges radiating from the central peaks (see Figure 1). This circumstance allowed us to consider each locality mentioned by Quayle, or visited by us, as part of a valley, even if there were surface differences between them $\left(x=16.4 \mathrm{~km}^{2} \pm 15.5\right)$. The total surface of the valleys compared historically represents $331 \mathrm{~km}^{2}$ and the total surface of the valleys visited in 1986-1991 was $640 \mathrm{~km}^{2}$ (61\% of Tahiti's surface). 


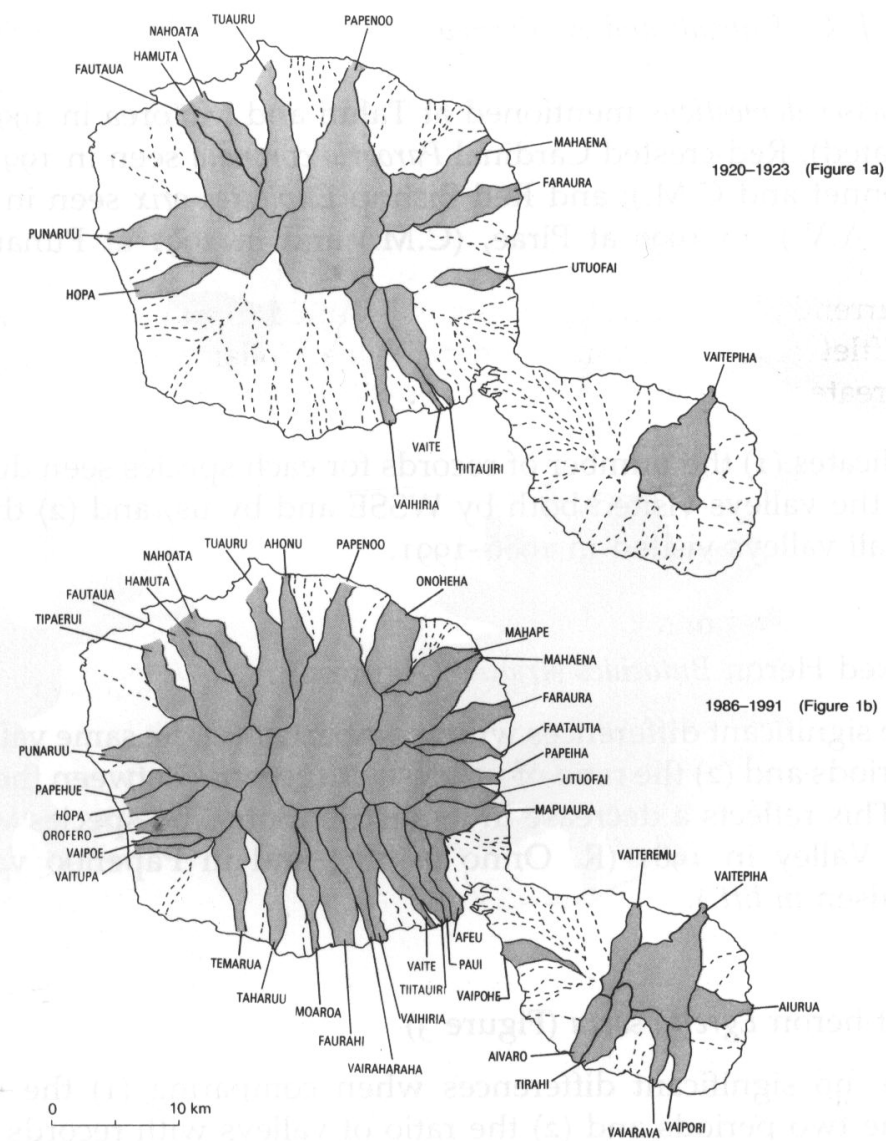

Figure 1. Valleys investigated in 1920-1923 and in 1986-1991. Dotted lines: ridges between valleys; uniform grey: valleys visited, species not encountered; hatching: species present.

For most species we present: (1) a map showing their distribution in the 14 localities visited by WSSE and (2) a map showing their present distribution in the 39 localities visited during the 1986-1991 period. As WSSE's data were too few to present a map for the Junglefowl, Feral Pigeon, Common Waxbill, Redbrowed Firetail and Chestnut-breasted Mannikin, we present maps showing only the present distribution for the three last species. For three other introduced species (Zebra Dove, Red-vented Bulbul and Crimson-backed Tanager), we also present an additional map, showing their exact distribution more accurately than an atlas map.

On individual distribution maps, the geographical limits of each valley are defined by their ridges and are represented by dotted lines. To test if the differences in the number of localities occupied between the two periods were statistically significant we used contingency tables (chi-square test and Fisher's Exact test).

We have dealt with all local landbirds and introduced birds which became well established during the twentieth century. We did not consider four recently introduced species whose survival is uncertain: Spotted Dove Streptopelia chinensis, seen in 1990 at Pirae (J.-C.T.), and in 1992 at Paea (Anon. 1992); House 
Sparrow Passer domesticus mentioned at Tahiti and Mo'orea in 1990 (Seitre and Seitre undated); Red-crested Cardinal Paroaria coronata seen in 1991 at Pirae (D. Valézy-Monnet and C.M.); and Red Bishop Euplectes orix seen in 1988 at Paea (C.M. and A.V.), in 1990 at Pirae, (C.M.) and in 1991 at Punauia (C. Payri verbally).

\section{Results}

Table 1 indicates (1) the number of records for each species seen during the two periods in the valleys visited both by WSSE and by us, and (2) the number of records in all valleys visited in 1986-1991.

\section{Green-backed Heron Butorides striatus (Figure 2)}

There were significant differences when comparing (1) the same valleys between the two periods and (2) the ratio of valleys with records between the two periods (Table 1). This reflects a decrease in its distribution. The species was also seen in Tuauru Valley in 1981 ( $R$. Onno in litt.) and in Papenoo valley in 1985 (M. K. Poulsen in litt.).

\section{Pacific Reef-heron Egretta sacra (Figure 3)}

There were no significant differences when comparing (1) the same valleys between the two periods and (2) the ratio of valleys with records between the two periods (Table 1).

Table 1. Distribution of Tahitian landbirds in 1920-1923 and 1986-1991. Tests indicate if differences in number of localities between the two periods are significant.

\begin{tabular}{|c|c|c|c|c|c|}
\hline Species & $\begin{array}{l}\text { Number of } \\
\text { valleys where } \\
\text { WSSE saw the } \\
\text { species, } \\
1920-1923 \\
(n=14)\end{array}$ & $\begin{array}{c}\text { Number of } \\
\text { valleys checked } \\
\text { in } 1920-1923 \text { and } \\
\text { where the } \\
\text { species was seen } \\
\text { in } 1986-1991 \\
(n=14)\end{array}$ & Test & $\begin{array}{c}\text { Number of } \\
\text { valleys where } \\
\text { the species } \\
\text { was seen in } \\
1986-1991 \\
(n=39)\end{array}$ & Test \\
\hline Butorides striatus & 10 & 3 & $P=0.009$ & 8 & $P=0.001$ \\
\hline Egretta sacra & 5 & 8 & N.S. & 25 & N.S. \\
\hline Anas superciliosa & 1 & 5 & N.S. & 14 & N.S. \\
\hline Circus approximans & 8 & 12 & N.S. & 28 & N.S. \\
\hline Porzana tabuensis & 2 & 3 & N.S. & 4 & N.S. \\
\hline Ptilinopus purpuratus & 10 & 13 & N.S. & 35 & N.S. \\
\hline Ducula pacifica & 3 & 2 & N.S. & 2 & N.S. \\
\hline Aerodramus leucophaeus & 2 & 3 & N.S. & 6 & N.S. \\
\hline Halcyon venerata & 10 & 14 & N.S. & 38 & $P=0.014$ \\
\hline Hirundo tahitica & 10 & 10 & N.S. & 21 & N.S. \\
\hline Acrocephalus caffer & 6 & 5 & N.S. & 12 & N.S. \\
\hline Pomarea nigra & 3 & 1 & N.S. & 4 & N.S. \\
\hline Acridotheres tristis & 7 & 12 & N.S. & 30 & N.S. \\
\hline
\end{tabular}



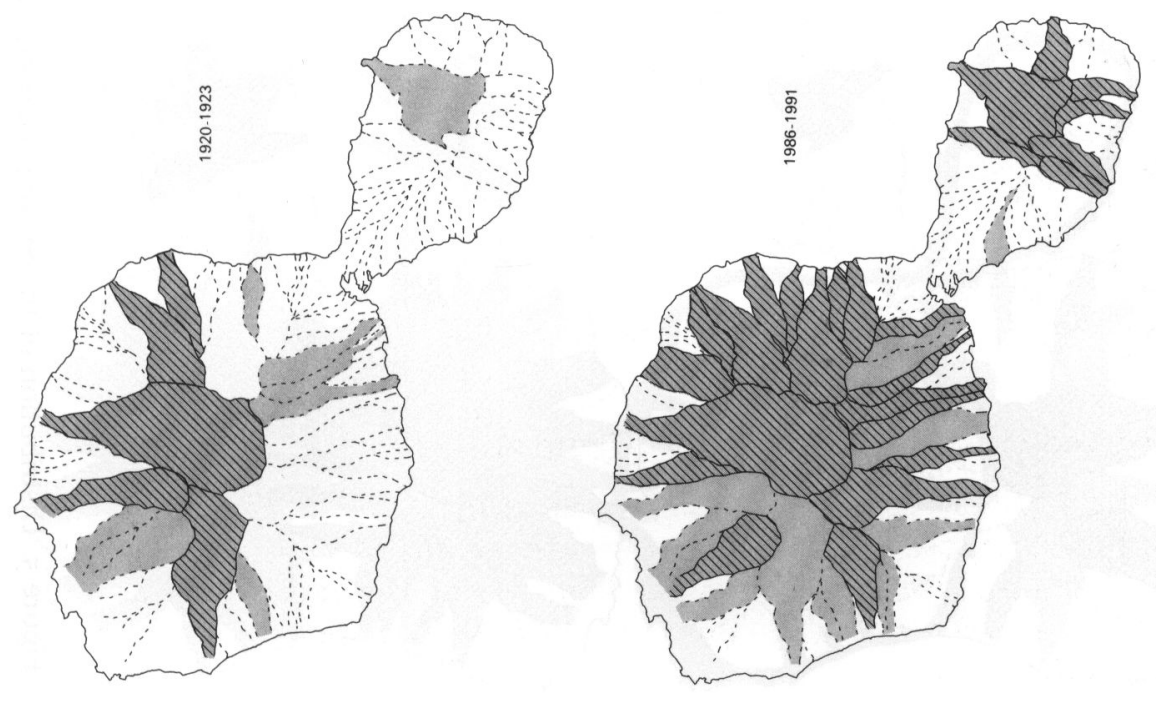

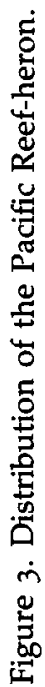
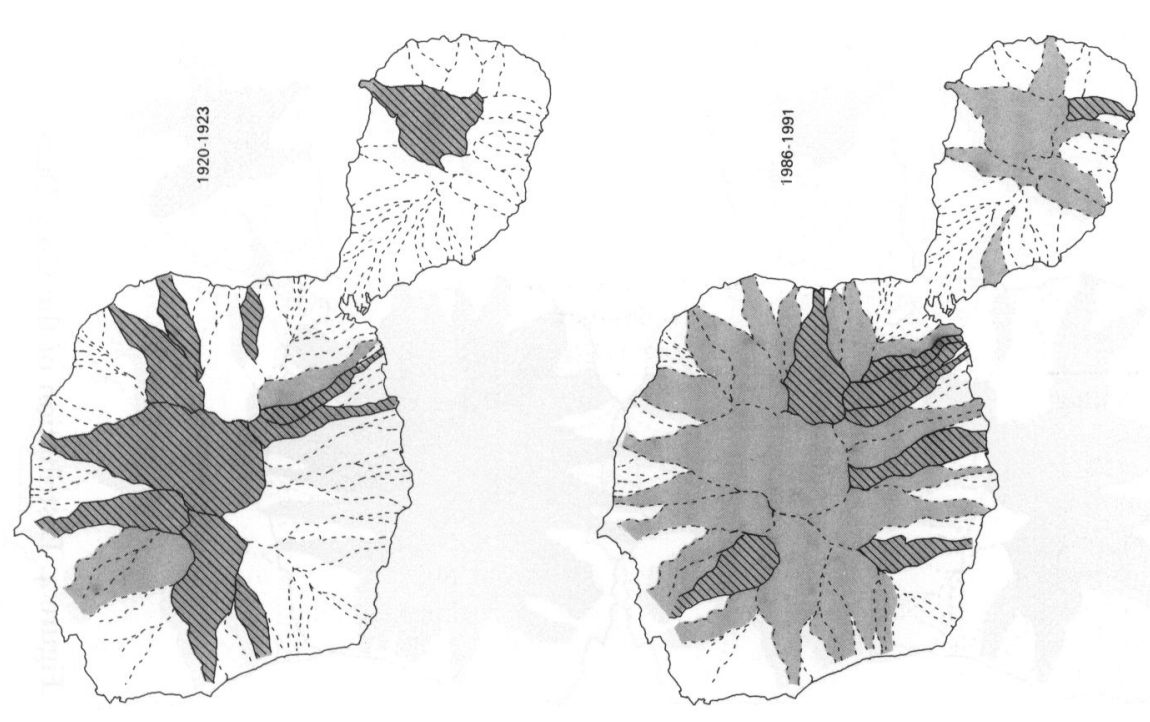

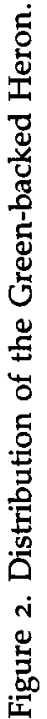



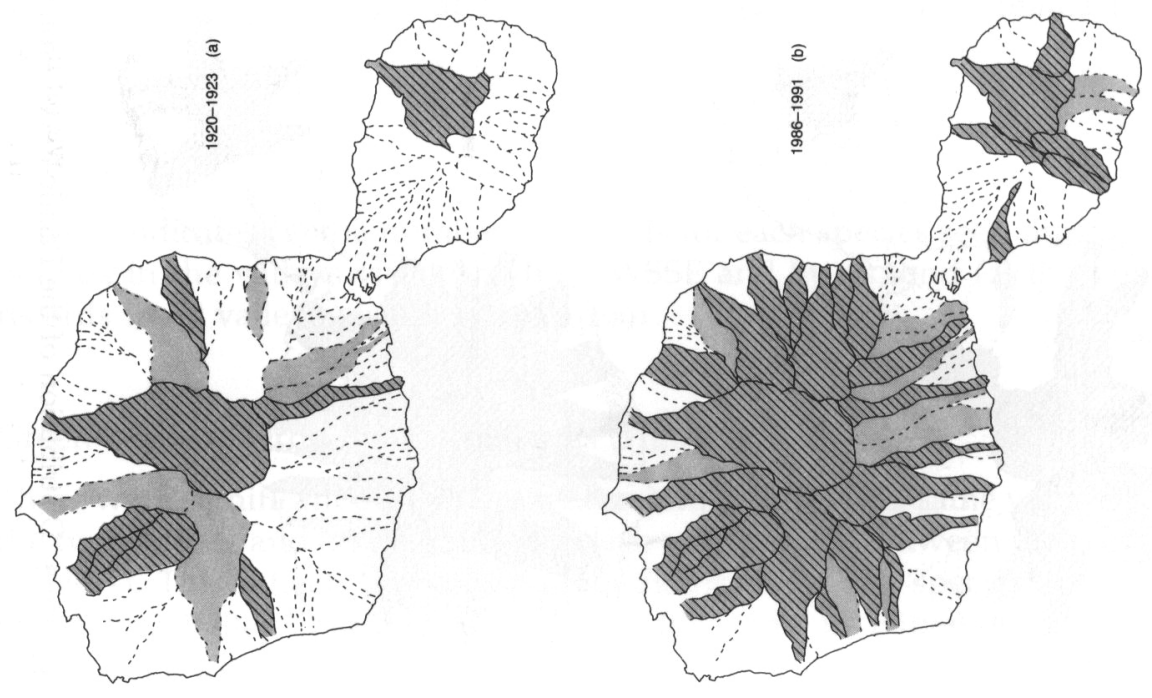

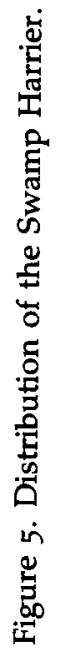
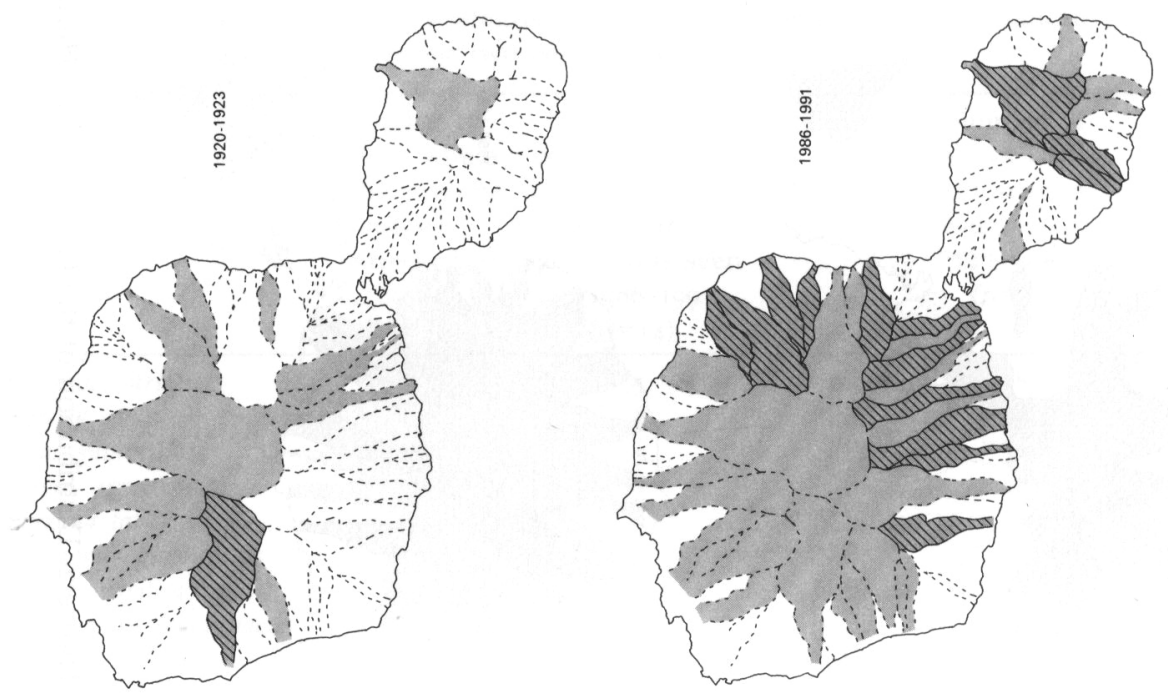

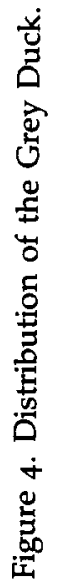



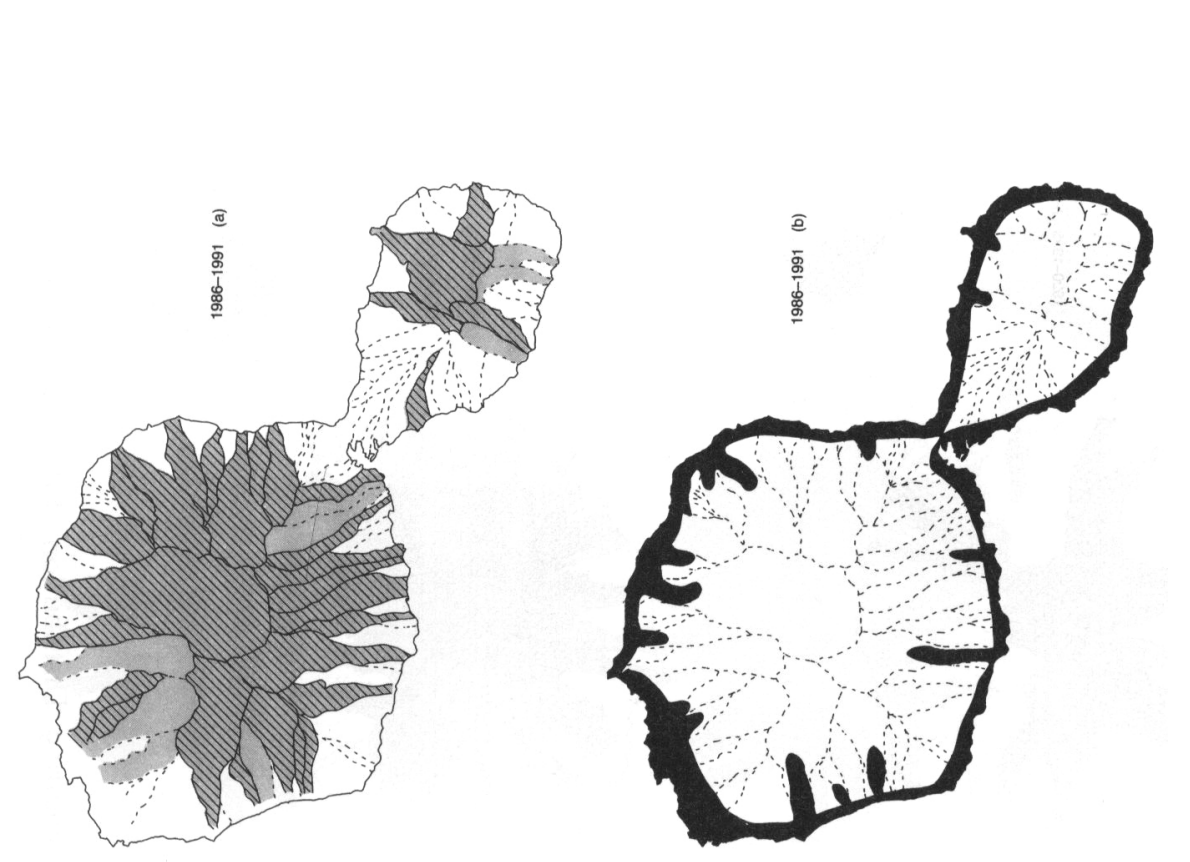

ક્

穴

홍

$\Xi \stackrel{\circ}{\circ}$

ن.

$\circlearrowleft .5$

옹

롤

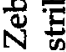

乎

돈

능

.

ق

营弯

$\therefore>$

造
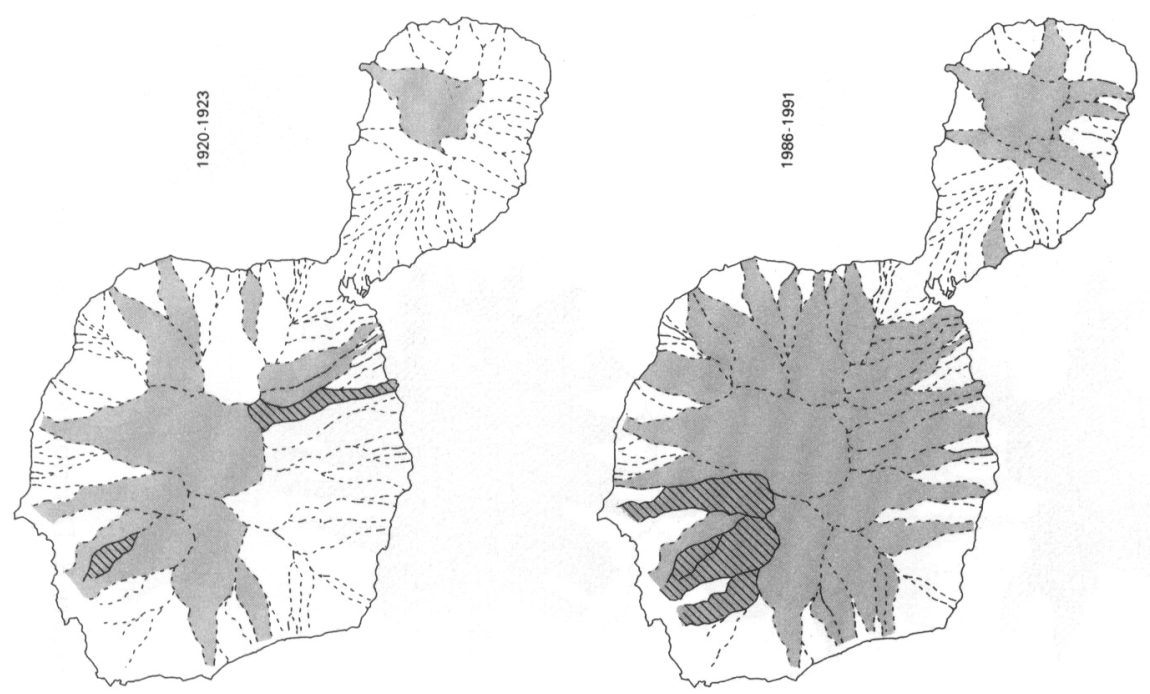

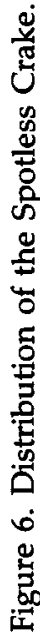



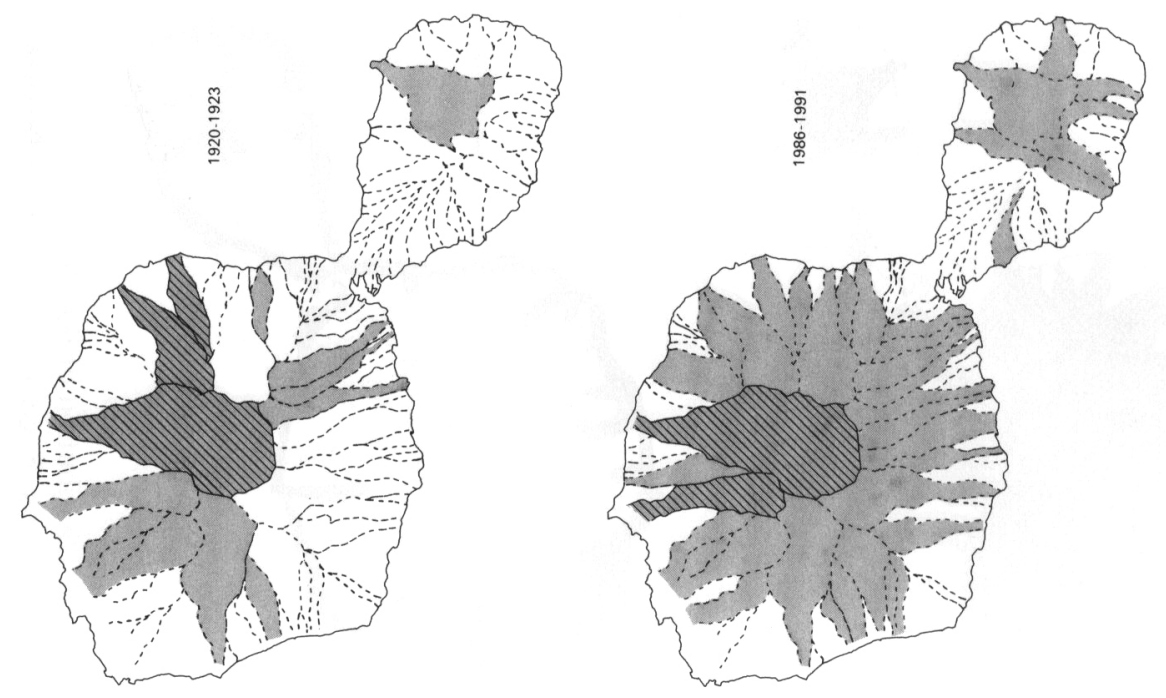

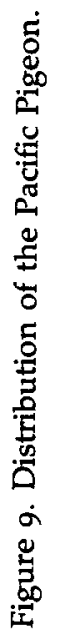
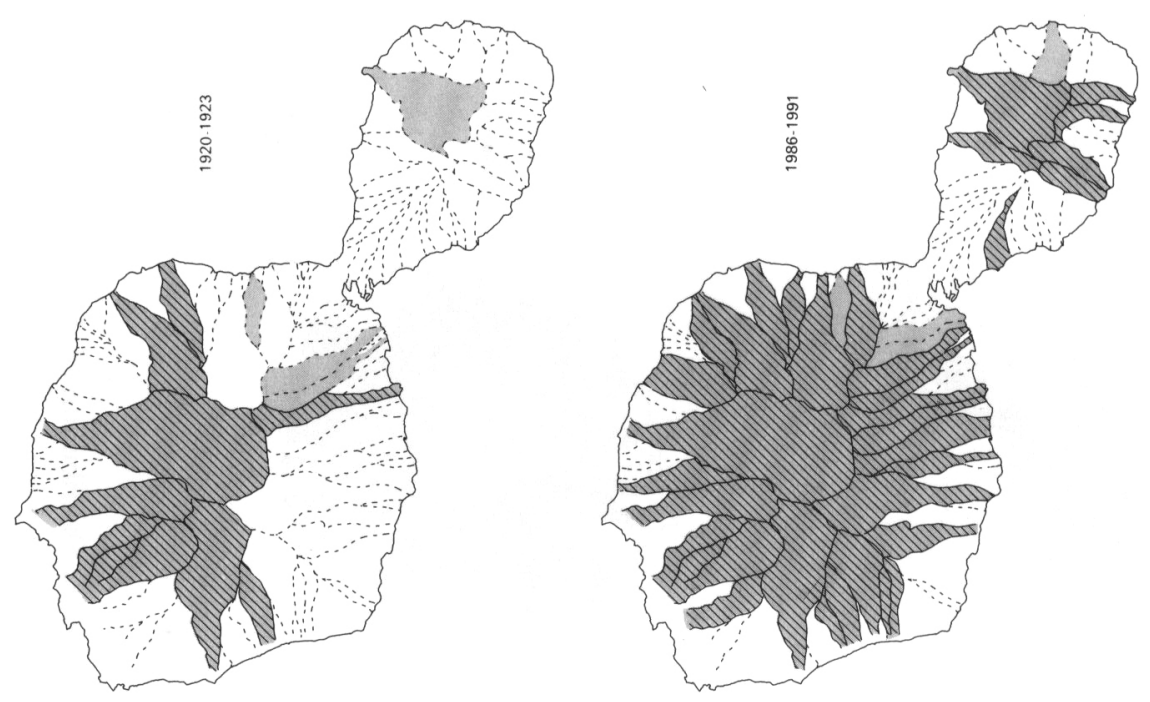

范 

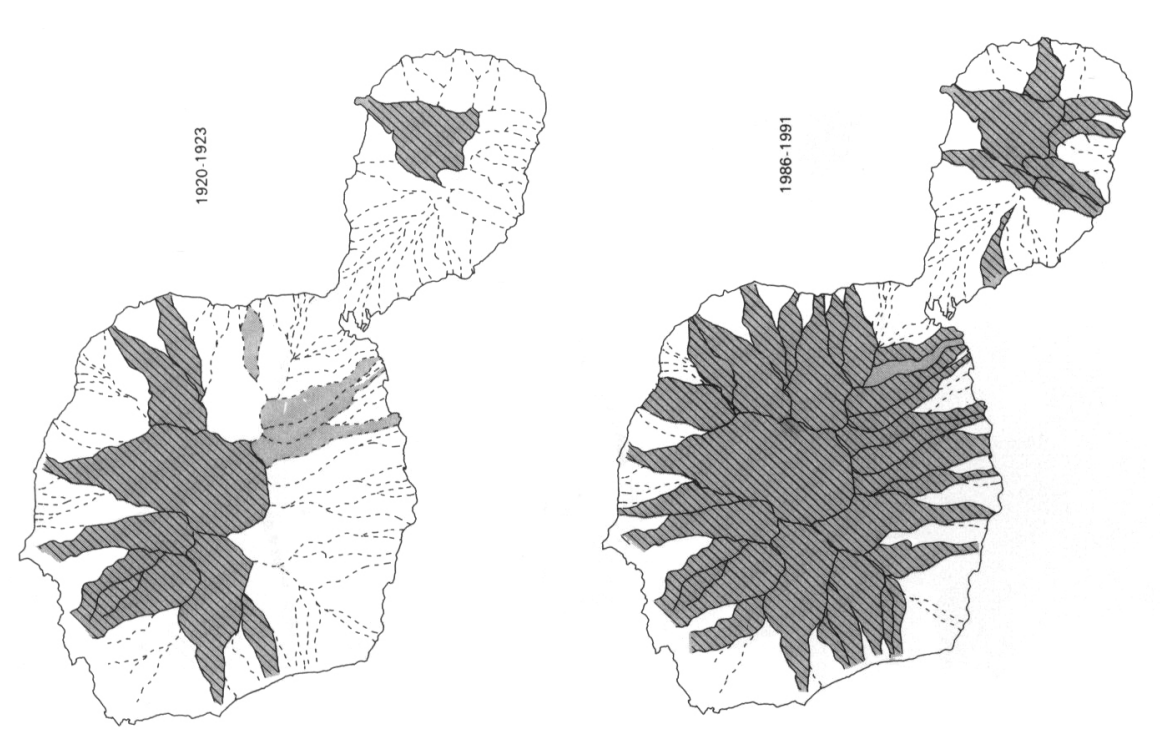

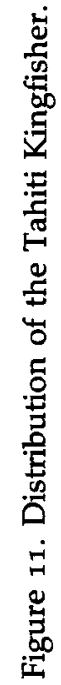
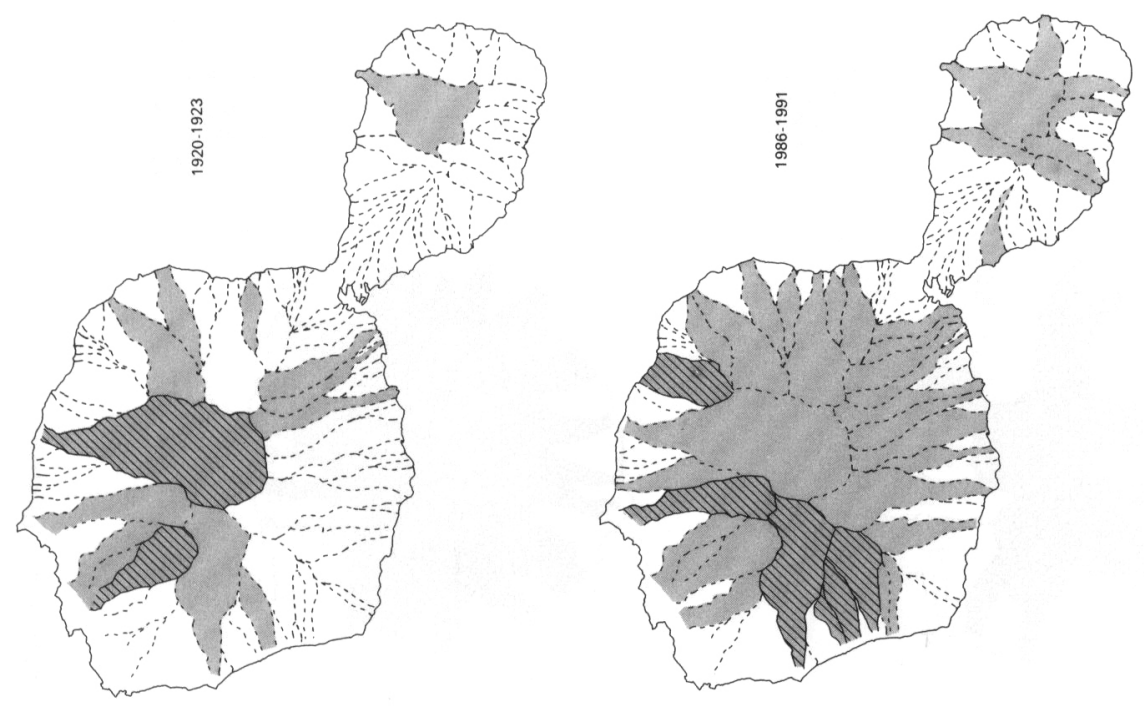

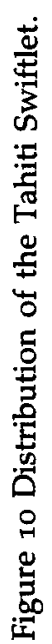



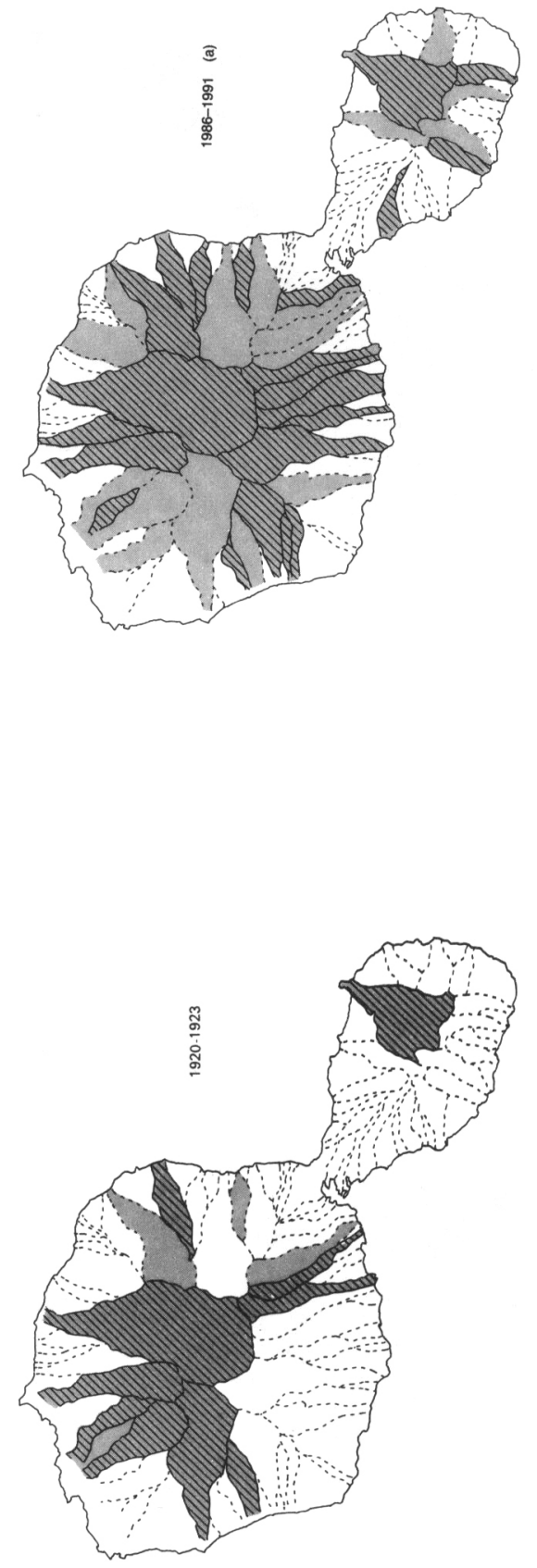

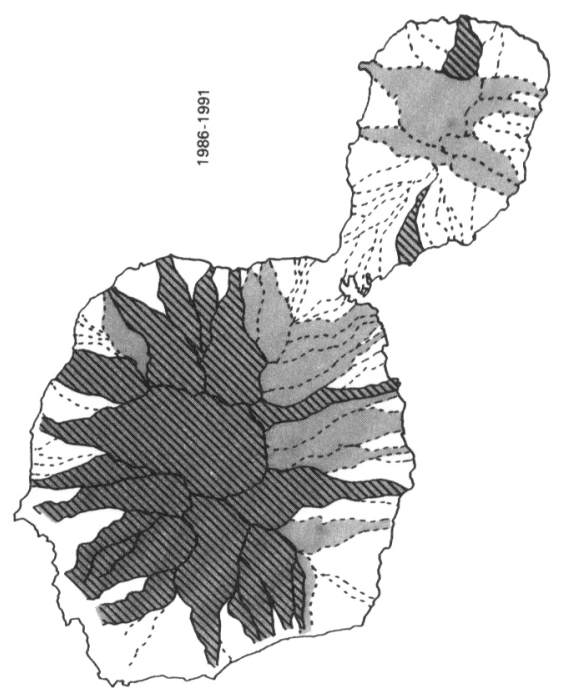

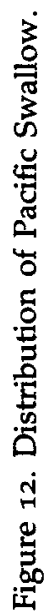



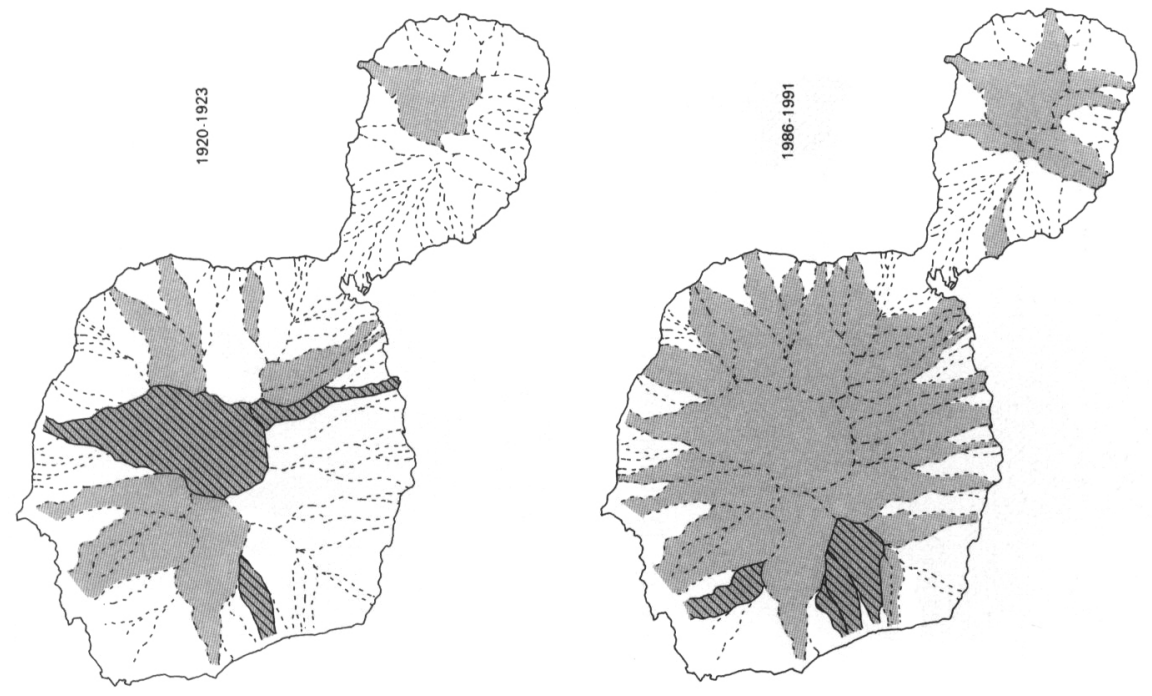

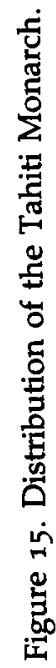
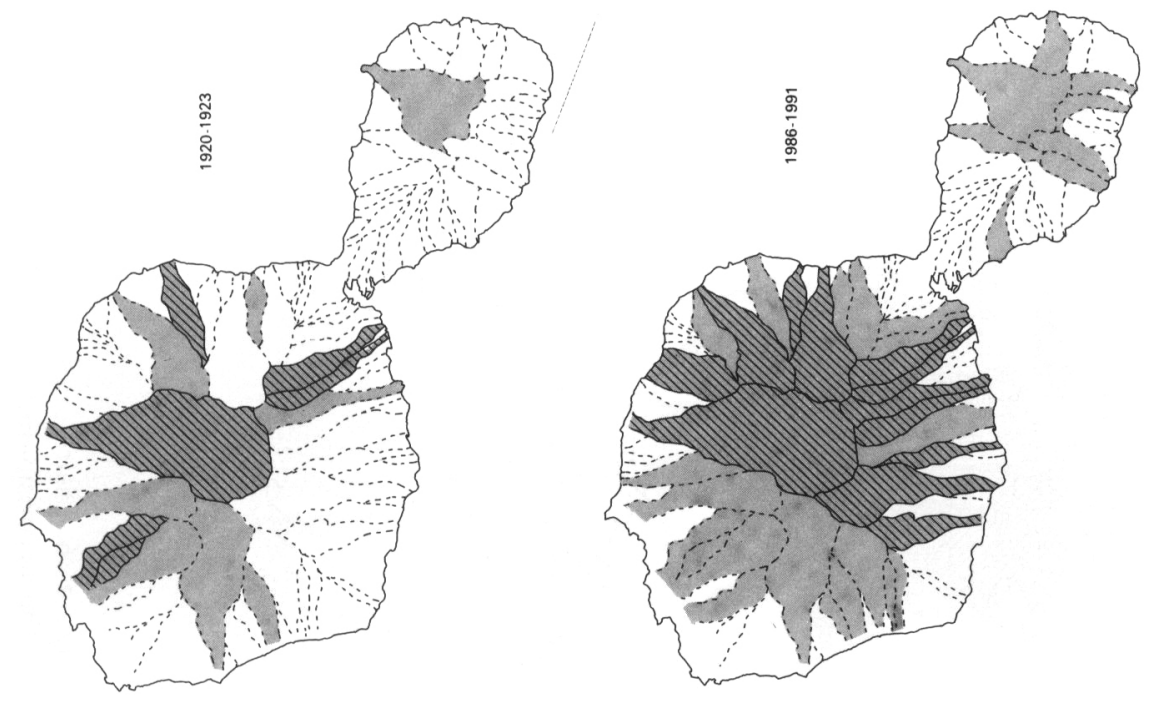

 

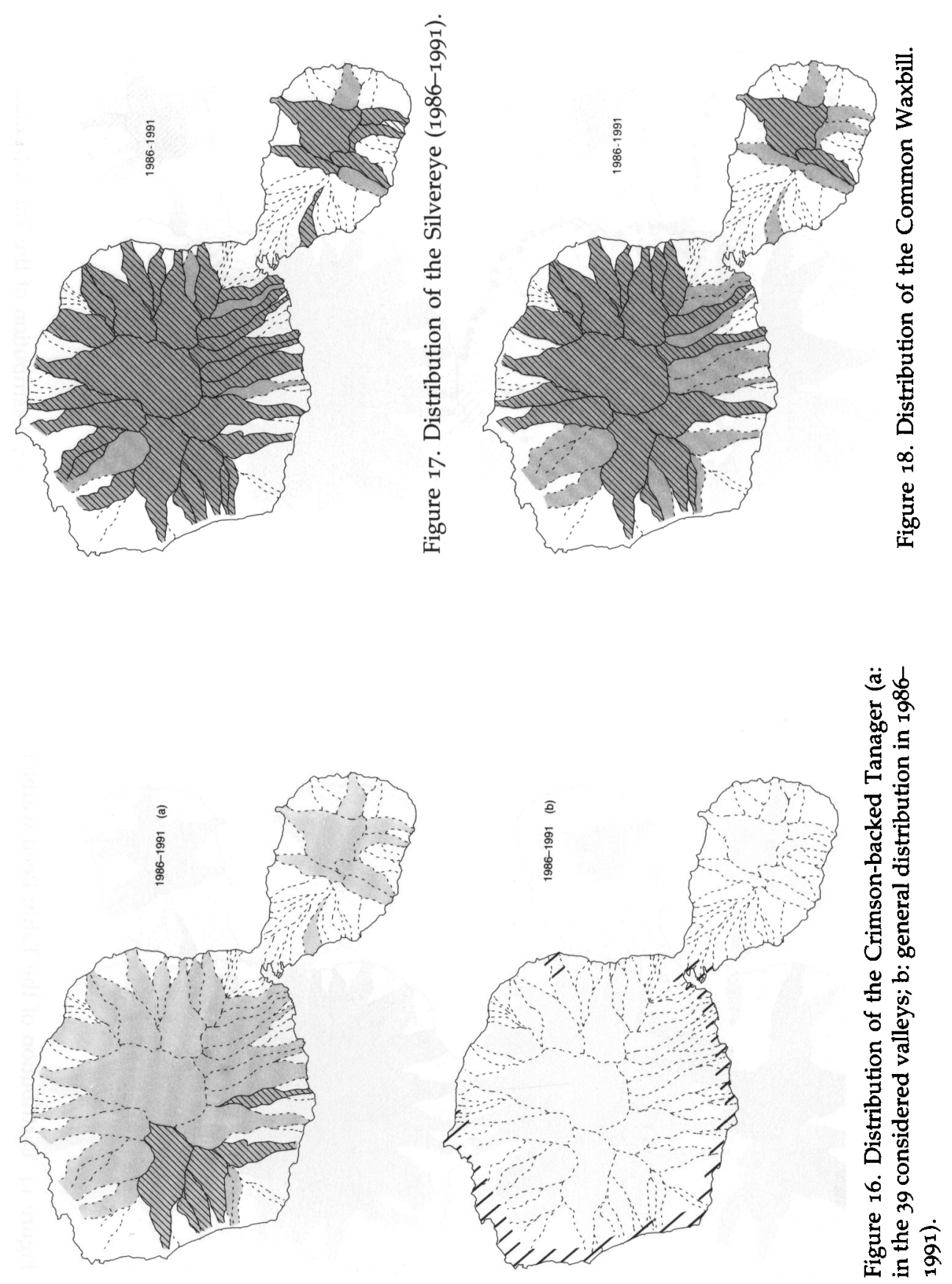

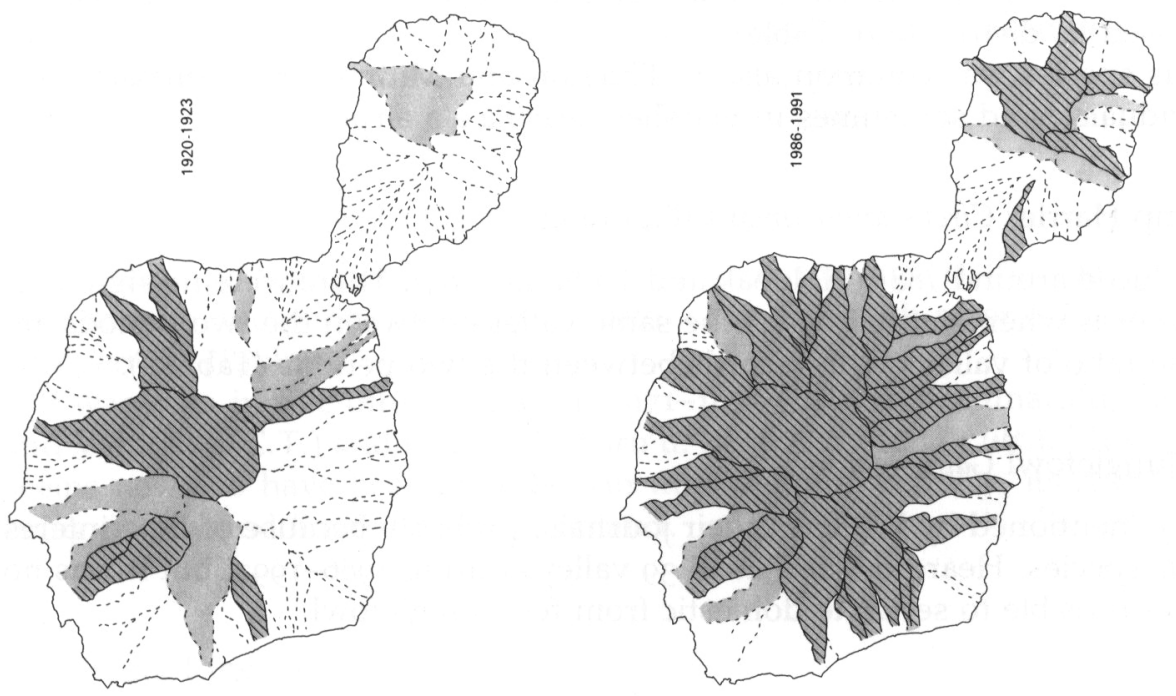

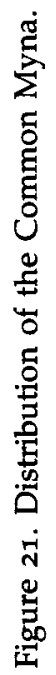
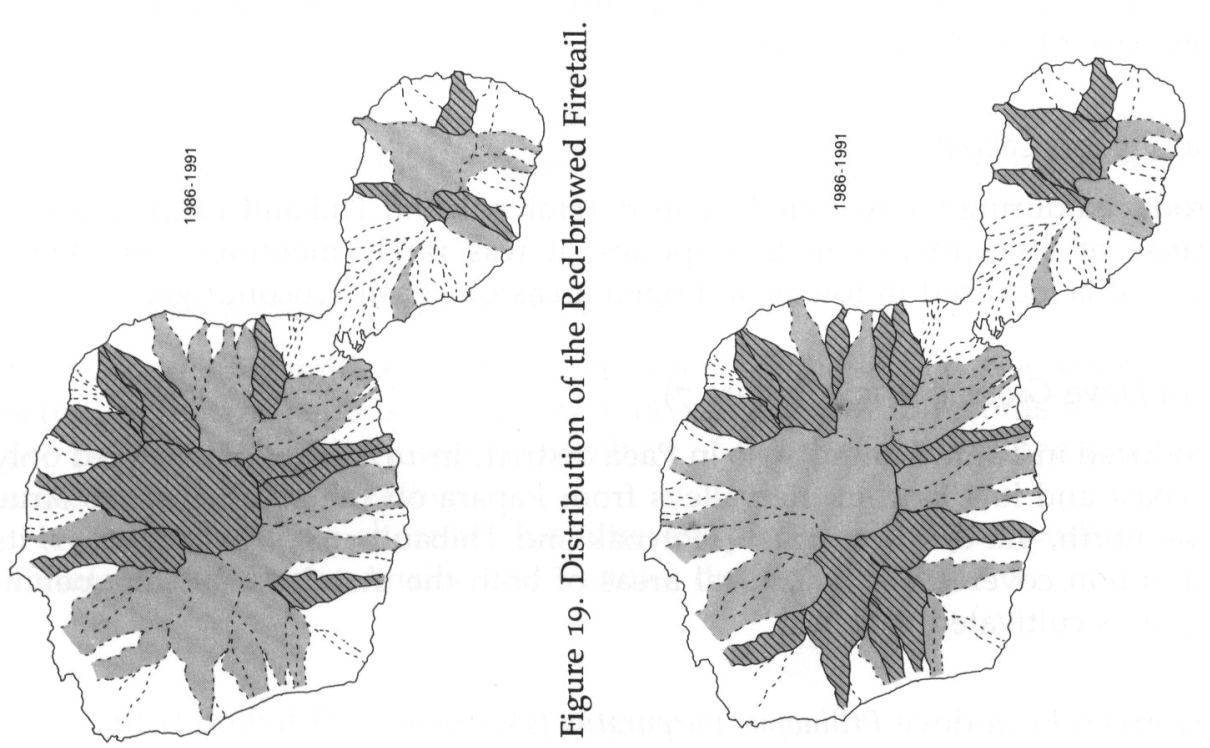

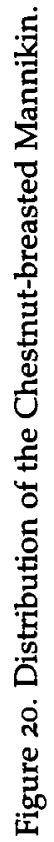


Grey Duck Anas superciliosa (Figure 4)

There were no significant differences when comparing the same valleys between the two periods (Table 1). Quayle wrote that it was rare, exterminated by the Swamp Harrier introduced 36 years before. However, the duck has recently increased its distribution (Table 1).

This species was common also in Phaeton and Mitirapa Bays (maximum 70 individuals), and sometimes in marshes near Fa'a'a airport.

\section{Swamp Harrier Circus approximans (Figure 5)}

Introduced around 1885 (Holyoak and Thibault 1984). There were no significant differences when comparing (1) the same valleys between the two periods and (2) the ratio of valleys with records between the two periods (Table 1).

\section{Red Junglefowl Gallus gallus}

Rarely mentioned by WSSE in their journals, probably because of little interest in this species. Heard or seen in all 39 valleys during 1986-1991, but it was not always possible to separate domestic from feral junglefowl.

\section{Spotless Crake Porzana tabuensis (Figure 6)}

There were no significant differences when comparing $(1)$ the same valleys between the two periods and (2) the ratio of valleys with records between the two periods (Table 1 ).

The species was noted in seven other localities during the 1971-1985 period (Mara'u, Arue, Papeno'o, Taravao, Vahiria: J.-C.T.; Pic Vert: R. Onno in litt.; Atimaono: M. K. Poulsen in litt.).

\section{Feral Pigeon Columba livia}

Introduced during the twentieth century (Holyoak and Thibault 1984). Probably because of little interest in this species, it was rarely mentioned by WSSE. Today, it is localized in towns and open areas on coasts (coconut groves).

\section{Zebra Dove Geopelia striata (Figure 7)}

Introduced in Tahiti around 1950 in Paea district. In 1971-1974, it occupied only the coast and low land in the valleys from Papara on the south coast to Arue in the north, via the west coast (Holyoak and Thibault 1984). In 1986-1991, its distribution covered all the coastal areas of both the mainland and the peninsula, plus cultivated valleys.

\section{Grey-green Fruit-dove Ptilinopus purpuratus (Figure 8)}

There were no significant differences when comparing (1) the same valleys between the two periods and (2) the ratio of valleys with records between the two periods (Table 1 ). 
Pacific Pigeon Ducula pacifica (Figure 9)

There were no significant differences when comparing (1) the same valleys between the two periods and (2) the ratio of valleys with records between the two periods (Table 1). This species has thus remained rare throughout the twentieth century and restricted to Papeno'o and Hitia'a valleys (Seale ms, Wilson 1907, Holyoak 1974).

\section{Tahiti Swiftlet Aerodramus leucophaeus (Figure 10)}

There were no significant differences when comparing (1) the same valleys between the two periods and (2) the ratio of valleys with records between the two periods (Table 1 ).

It was seen in five other valleys in 1971-1975 (Papeno'o, Punaru'u, Fautaua and Vahiria: J.-C.T.) and in 1984 (Taharu'u: M. K. Poulsen in litt.). This species seems never to have been abundant in the twentieth century, its distribution being patchy and limited to the mainland.

\section{Chattering Kingfisher Halcyon tuta}

This bird was not observed by WSSE, or by us. Collected by Wilson (1907) in 1904, it was seen by Holyoak (1974) in Mataia village.

\section{Tahiti Kingfisher Halcyon venerata (Figure 11)}

There were no significant differences when comparing the same valleys between the two periods; but there was a significant difference when comparing the ratio of valleys with records between the two periods. It was present in a greater number of valleys in 1986-1991 (Table 1), and this may reflect a recent increase.

\section{Pacific Swallow Hirundo tahitica (Figure 12)}

There were no significant differences when comparing (1) the same valleys between the two periods and (2) the ratio of valleys with records between the two periods (Table 1). However, numbers of the species remained low (rarely more than 1-4 pairs together).

It was seen on the shore in five different places in the peninsula (Anaotu, Vaitutaepua'a, Taura, Anaihe and Vaitoto) during 1986-1991.

\section{Red-vented Bulbul Pycnonotus cafer (Figure 13)}

Introduced on Tahiti at the end of the 1970s (Bruner 1979). In less than 1o years it occupied nearly all the coastal areas on the mainland and the peninsula, and also several areas inland up to $1,500 \mathrm{~m}$. 
Tahiti Reed-warbler Acrocephalus caffer (Figure 14)

There were no significant differences when comparing (1) the same valleys between the two periods and (2) the ratio of valleys with records between the two periods (Table 1 ). It has never been found on the peninsula.

\section{Tahiti Monarch Pomarea nigra (Figure 15)}

There were no significant differences when comparing (1) the same valleys between the two periods and (2) the ratio of valleys with records between the two periods (Table 1 ). However, recently it has become rarer at Mt Mara'u where it was quite common in the 1970s (Holyoak and Thibault 1984).

\section{Crimson-backed Tanager Ramphocelus dimidiatus (Figure 16)}

Introduced in the 1930s (Holyoak and Thibault 1984). In 1974 it was confined to gardens and cultivations in Puna'uia, Pa'e'a and Taravao villages. In 19861991, it had spread to the north (Mahina) and was seen at Hitia'a (J. Drollet verbally).

\section{Silvereye Zosterops lateralis (Figure 17)}

Introduced around 1937 (Holyoak and Thibault 1984). Apparently uncommon in the 1950s (King 1958), it was abundant all over the island in the 1970s. In 1986-1991, it was recorded in most of the valleys visited.

\section{Common Waxbill Estrilda astrild (Figure 18)}

Introduced between 1908 and 1919 (Holyoak and Thibault 1984). Records by WSSE were too scarce to be taken account of; we do not know if the species was rare or if it was not systematically registered by WSSE. In 1986-1991, it was found in 20 localities on the mainland and the peninsula.

\section{Red-browed Firetail Emblema temporalis (Figure 19)}

Introduced at the end of the nineteenth century (Holyoak and Thibault 1984). Records by WSSE were too scarce to be taken account of. In 1986-1991, it was found in 12 localities on the mainland and the peninsula.

\section{Chestnut-breasted Mannikin Lonchura castaneothorax (Figure 20)}

Introduced at the end of the nineteenth century (Holyoak and Thibault 1984). Records by WSSE were too scarce to be taken account of. In 1986-1991, it was found in 15 localities on the mainland and the peninsula. 
Common Myna Acridotheres tristis (Figure 21)

Introduced between 1908 and 1915 (Holyoak and Thibault 1984). There were no significant differences when comparing (1) the same valleys between the two periods and (2) the ratio of valleys with records between the two periods (Table 1).

\section{Discussion}

A comparison of information in WSSE journals with present data had already been attempted for several small islands of eastern Polynesia (Thibault and Guyot 1987, Thibault 1989), but never before a comparison of the same areas over time on a major island in the central Pacific. It is very satisfying that the accuracy of Quayle's notes has allowed us to compare the situation of most components of the Tahitian avifauna over an interval of 70 years. For several introduced species, however, the early data were too scarce to be used.

Since the WSSE visit, there has been no extinction of a native landbird, nor any extinction of established introduced species, although several species introduced in the 1940s disappeared soon after their release (Holyoak and Thibault 1984). We noted no colonization of new species from other archipelagos. Finally, the composition of the peninsula's avifauna has not changed and is poorer than that of the mainland: the Pacific Pigeon, Tahiti Reed-warbler and Tahiti Monarch have remained absent throughout the twentieth century. For most species the distribution maps for the 1986-1991 period reflect the situation well, except for the Spotless Crake whose distribution was probably more extended than shown.

Three categories of birds may be recognized: (1) species with contracting ranges, (2) species with stable or expanding ranges, and (3) newly introduced species. Today, introduced birds represent more than half of the Tahitian avifauna.

1. Species with contracting ranges. We noticed only one species, the Greenbacked Heron, represented by an endemic form (B. s. patruelis). Its decrease comes from changes in habitat owing to hydroelectric power works, channelization, and forest clearance along rivers and on coasts around the lagoon. This heron was seen for the last time on the Punaru'u and Vaitepiha rivers in 1971-1975. Today, it lives in a limited number of undisturbed areas on the southern and eastern coasts of the mainland, and also on the coast of the peninsula.

2. Species with stable ranges. We distinguish between: (i) introduced species which are well distributed today (Swamp Harrier, Red Junglefowl, Feral Pigeon, Common Waxbill, Red-browed Firetail, Chestnut-breasted Mannikin and especially Common Myna), (ii) well distributed species tolerating some changes in habitat (Pacific Reef-heron, Grey-green Fruit-dove, Tahiti Kingfisher, Pacific Swallow) and (iii) rare and localized species (Grey Duck, Spotless Crake, Pacific Pigeon, Tahiti Swiftlet, Chattering Kingfisher, Tahiti Monarch and Tahiti Reed-warbler), for which the following remarks may be made.

Despite the draining of ponds and marshes, and forest clearance along 
rivers, the Grey Duck has remained stable thanks to the exploitation of new resources, such as crayfish breeding basins.

For a century the Pacific Pigeon in Tahiti has been represented by an isolated population whose numbers have remained very small; without knowing the total involved and the species population dynamics it is impossible to judge how long this situation may continue. As hunting stopped several decades ago, other factors must be responsible for keeping its population to such a low level; Holyoak and Thibault (1978) suggested that the Swamp Harrier might be a predator. Seitre and Seitre (1992) consider it a possibly extinct species owing to hunting and habitat destruction.

During the twentieth century, the Tahiti Swiftlet remained rare and localized on Tahiti, although it is common in most of the Marquesas Islands. But there is a relation between its scarcity or extinction and the introduction of the Common Myna, a possible predator of eggs or young (e.g. Hiva Oa in Marquesas: Holyoak and Thibault 1984).

Although the Tahiti Monarch has been rare throughout the twentieth century, it was formerly common (Peale 1848); its recent decrease on Mt Mara'u might be related to the replacing of the high, dense forest by shrubs of the botanical pest Miconia calvescens, introduced in 1937, whose progression was partly facilitated by the 1983 hurricane (Birnbaum 1992).

Seale (ms) and Quayle (ms) noticed that the Tahiti Reed-warbler was associated with bamboo groves. This is still the case today on the mainland, but curiously enough the warbler is absent from the peninsula where bamboos are common.

3. Introduced species. Several newly introduced birds - Zebra Dove, Redvented Bulbul, Silvereye and Crimson-backed Tanager - have showed a marked increase, but each of them with a different pattern of colonization. The Zebra Dove has rapidly colonized coasts and low valleys of Tahiti and Mo'orea, although the process has needed at least 40 years (Thibault and Monnet 1993). The Red-vented Bulbul also exhibited very rapid progress: in less than 10 years, it colonized all coastal Tahiti, its secondary forest up to $1,500 \mathrm{~m}$, and other islands in the vicinity (Mo'orea: C.M.; Raiatea: Anon. 1992 and P. Raust verbally). The Silvereye has been a very active colonizer, occupying in less than 30 years all the islands of the Society archipelago, Austral Islands and Makatea in north-west Tuamotu (Thibault and Monnet 1990). Fifty years after its release, the Crimson-backed Tanager population remains small and its distribution limited to a small area on the coast, although its progress has been steady from 1975 to 1991.

Changes in the local Tahitian avifauna have been relatively less important during the twentieth than during the previous century, when several species disappeared (Thibault 1988). On the other hand, more exotic species were released during the twentieth century. We may also notice that: (1) surviving native landbirds coexist with introduced birds and are able to endure some habitat modification, the most sensitive species, like members of the Psittacidae, having become extinct long since; (2) because of their small population numbers, two species, the Pacific Pigeon and the Tahiti Monarch, are on the verge of extinction even if their distribution has not notably changed during this century. 


\section{Acknowledgements}

We express our thanks to Dr D. T. Holyoak for comments on a first draft of the manuscript, to Jaqui Drollet, Jacques Florence, Philippe Siu and the Délégation à l'Environnement from Polynesia for their help in Tahiti, to Elisabeth Auberton, Michel Danard and J.-C. Janicaud (ORSTOM) who drew the maps, and to the late René Onno and M. K. Poulsen who kindly sent us original data on the birds of Tahiti.

\section{References}

Anon. (1992) A vos jumelles. Te Manu, Papeete (1): 3 .

Belwood, P. (1978) The Polynesian: prehistory of an island people. London: Thames and Hudson.

Blanchet, G. (1986) L'évolution économique et démographique de 1960 à 1986. Pp.25-40 in F. Ravault, ed. Vivre en Polynésie 1. Encyclopédie de la Polynésie 8. Papeete: Christian Gleizal/Multipress.

Birnbaum, P. (1992) Contribution à l'étude du processus par lequel une plante introduite devient envahissante: le cas de Miconia calvescens à Tahiti (Polynésie française). D.E.A., Université des Sciences et Techniques du Languedoc, Montpellier.

Bruner, A. (1979) Red-vented Bulbul now in Tahiti. Elepaio 40: 92.

Bryan, E. H. Jr. (ms) Chronological summary and guide to the Whitney Expedition journals held in the American Museum of Natural History, New York.

Collar, N. J. and Andrew, P. (1988) Birds to watch; the ICBP world check-list of threatened birds. Cambridge, U.K.: International Council for Bird Preservation (Techn. Publ. 8).

Holyoak, D. T. (1974) Les oiseaux des îles de la Société. Oiseau et R.F.O. 44: 1-27, 153184.

Holyoak, D. T. and Thibault, J.-C. (1978) Notes on the phylogeny, distribution and ecology of frugivorous pigeons in Polynesia. $\operatorname{Emu} 78$ : 201-206.

Holyoak, D. T. and Thibault, J.-C. (1984) Contribution à l'étude des oiseaux de Polynésie orientale. Mém. Mus. Natn. Hist. Nat. 127: 1-209.

King, J. E. (1958) Some observations on the birds of Tahiti and the Marquesas Islands. Elepaio 19: 14-17.

Mayr, E. (1939) The origin and history of the bird fauna of Polynesia. Proc. 6th Pacific Sci. Congr., Berkeley 4: 197-216.

Peale, T. R. (1848) U.S. Exploring Expedition during the years $1838-1842$, etc. Mammalogy and Ornithology, in vol. 8. Philadelphia.

Seale, S. C. (ms) Expedition to South Eastern Polynesia, 1901-1902. Lodged at the Library of the Bernice P. Bishop Museum, Honolulu.

Seitre, R. and Seitre, J. (undated) Causes de disparition des oiseaux terrestres de Polynésie française. SPREP Occas. Pap. Ser. 8: 1-92.

Seitre, R. and Seitre, J. (1992) Causes of land-bird extinctions in French Polynesia. Oryx 26: 215-222.

Steadman, D. W. (1988) Fossil birds and biogeography in Polynesia. Acta XIX Congr. Internatn. Orn., Ottawa: 1526-1534.

Thibault, J.-C. (1988) Menaces et conservation des oiseaux de Polynésie française. Pp. 87-124 in J.-C. Thibault and I. Guyot, ed. Livre rouge des oiseaux menacés des régions françaises d'outre-mer. Saint-Cloud: International Council for Bird Preservation (Monogr. 5).

Thibault, J.-C. (1989) L'avifaune des îles Eiao et Hatuta'a (Polynésie, Pacifique sud): modifications intervenues au XXème siècle. Oiseau et R.F.O. 59: 305-324.

Thibault, J.-C. and Guyot, I. (1987) Recent changes in the avifauna of Makatea Island (Tuamotus, Central Pacific). Atoll Res. Bull. 300. 
Thibault, J.-C. and Monnet, C. (1990) Le Zosterops à poitrine grise Zosterops lateralis (Latham) en Polynésie: un oiseau introduit devenu colonisateur actif. Oiseau et R.F.O. 6o: 233-240.

Thibault, J.-C. and Monnet, C. (1993) Les oiseaux en Polynésie, planche 57. In Atlas de la Polynésie Française. ORSTOM Edition.

Wilson, S. B. (1907) Notes on birds of Tahiti and the Society Group. Ibis (9)3: 373-379.

\section{CLAUDE MONNET}

Institut Français de Recherche Scientifique pour le Développement en Coopération, Centre O.R.S.T.O.M. de Tahiti, B.P.529, Pape'ete, Tahiti, French Polynesia.

\section{JEAN-CLAUDE THIBAULT}

Centre de Recherches Insulaires et Observatoire de l'Environnement, B.P.1013, Papetoai, Mo'orea; (present address) Parc Naturel Régional de la Corse, B.P. 417, F-20184, Corsica.

\section{ALBERT VARNEY}

Délégation à l'Environnement, B.P. 4562, Papéete, Tahiti, French Polynesia. 